\title{
Malignant melanoma of the eyelid skin: histopathology and behaviour
}

\author{
A GARNER,' L KOORNNEEF, ${ }^{2}$ A LEVENE, ${ }^{3}$ AND J R O COLLIN ${ }^{4}$
}

From the 'Department of Pathology, Institute of Ophthalmology, University of London, 17-25 Cayton Street, London ECIV 9AT; the ${ }^{2}$ Orbital Centre, Academisch Medisch Centrum, Meibergdreef 9 , 1105 AZ Amsterdam, The Netherlands; the ${ }^{3}$ Department of Histopathology, the Royal Marsden Hospital, Fulham Road, London SW3 6JJ; and ${ }^{4}$ Moorfields Eye Hospital, City Road, London EC1V 9PD

SUMMARY Histological sections from 24 patients with malignant melanoma of the eyelid skin were studied and correlated with clinical follow-up for an average of 8.6 years. There was an average post-treatment follow-up of $7 \cdot 4$ years with a cure rate of $78 \%$ in the superficial spreading group. The average follow-up in the nodular melanoma group was 9.4 years with a cure rate of $75 \%$. Nodular melanoma patients with the lesion in the lid margin have a worse prognosis than those with the lesion on the eyelid skin.

Malignant melanoma of the eyelids, apart from the conjunctival surface, accounts for about $1 \%$ of all eyelid tumours' and slightly less than $7 \%$ of cutaneous malignant melanoma in the head and neck region. ${ }^{2}$ Because of its rarity descriptions have been based on the study of small groups or isolated cases, and it has been difficult to establish a comprehensive and representative picture of the histology and behaviour of malignant melanoma in this situation. In the following account we describe the prognosis and histopathology in 24 patients followed up for between three and 33 years.

\section{Patients and methods}

A total of 24 patients, for whom adequate follow-up information was available, were included in the series. Their ages ranged from 18 to 80 years, with a majority presenting in the 6th and 7th decades. Females (15) were affected slightly more commonly than males (9). More than half of the tumours were located on the eyelid margin, and a further half of these were unpigmented. The upper lid was affected in 16 patients the lower lid in eight. The distribution was equal in the medial and lateral areas of the eyelids. Although it was not possible to comment on the clinical presentation of the tumours because of the retrospective nature of the majority in this study, $25 \%$ of the patients were seen preoperatively by one

Correspondence to Professor A Garner. of the authors (RC). Patients who presented clinically with a flat lesion (Fig. 1) were most likely to have a superficial spreading malignant melanoma than were patients presenting with a bulky or marginal lesion (Fig. 2), who were more likely to have a nodular melanoma.

In our series 21 patients had surgery, two had irradiation, and one both treatments.

The type of surgery varied with the size of the lesion. The margins of the excised specimens were histologically clear in 22 patients. In two patients in whom clearance was incomplete a second surgical procedure was performed with complete removal of

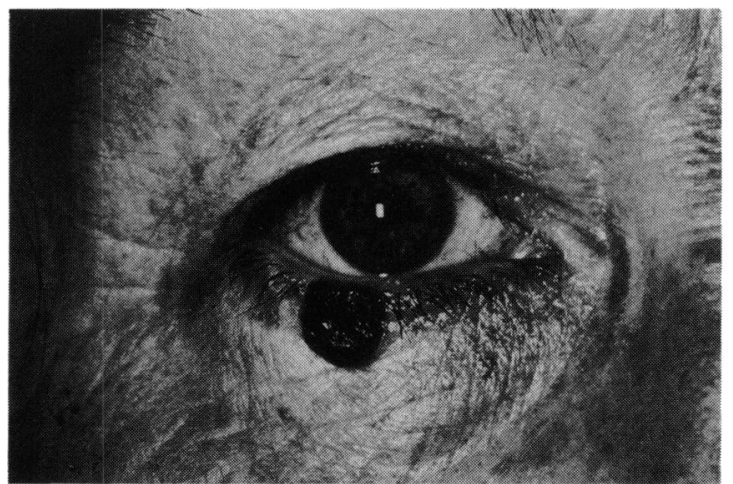

Fig. 1 Case 8. Clinical picture of a superficial spreading malignant melanoma. 


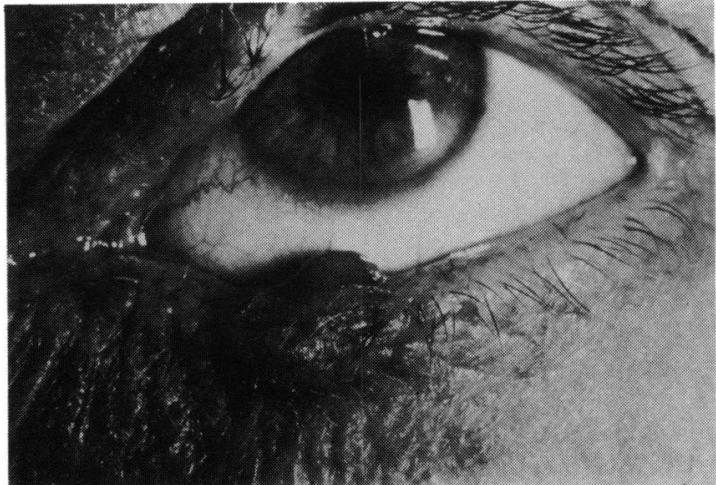

Fig. 2 Clinical appearance of an unpigmented nodular melanoma of lid margin.

the residual tumour. No figures are available on the number of patients who were subjected to a diagnostic as opposed to an excisional biopsy.

Histological sections were examined from each of the 24 patients. The sections were drawn from the files of the Institute of Ophthalmology, London (21 cases), the Dutch Cancer Institute at the Antoni van Leeuwenhoek Ziekenhuis (two cases), and the Royal Marsden Hospital, London (one case). Representative haematoxylin and eosin stained sections, including bleached preparations, were reviewed by two of the authors (AG and AL) using diagnostic criteria as defined by Levene. ${ }^{3}$ Three categories of invasive melanoma were recognised for the purpose of classi-

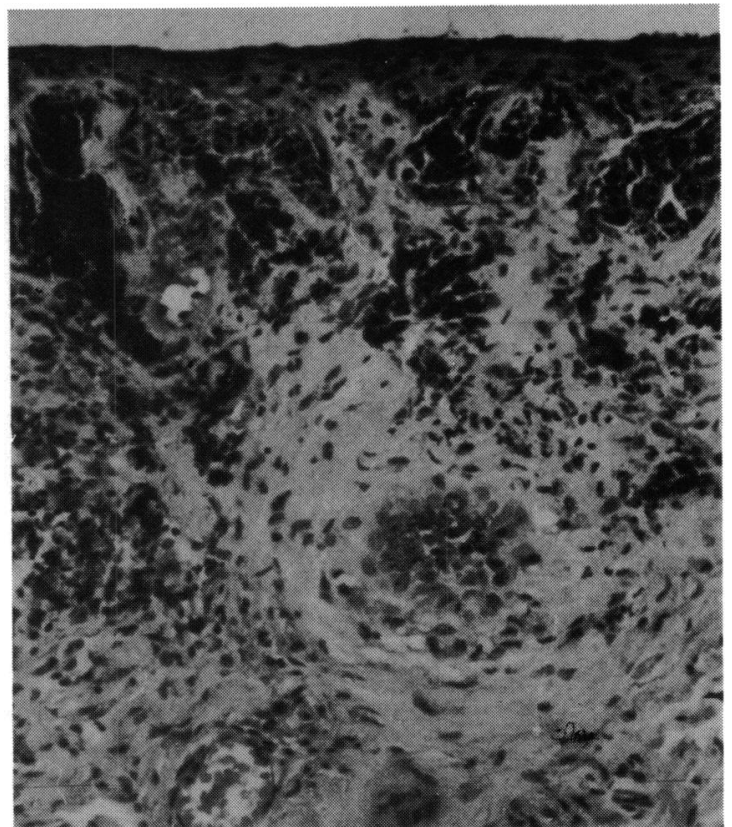

Fig. 3 Case 3. Superficial spreading malignant melanoma. Invasion by heavily pigmented, pleomorphic tumour cells is confined to the epidermis and superficial stroma.

(Haematoxylin and eosin, $\times 160$ ).

fication: lentigo maligna melanoma, superficial spreading malignant melanoma, and nodular malignant melanoma. ${ }^{45}$

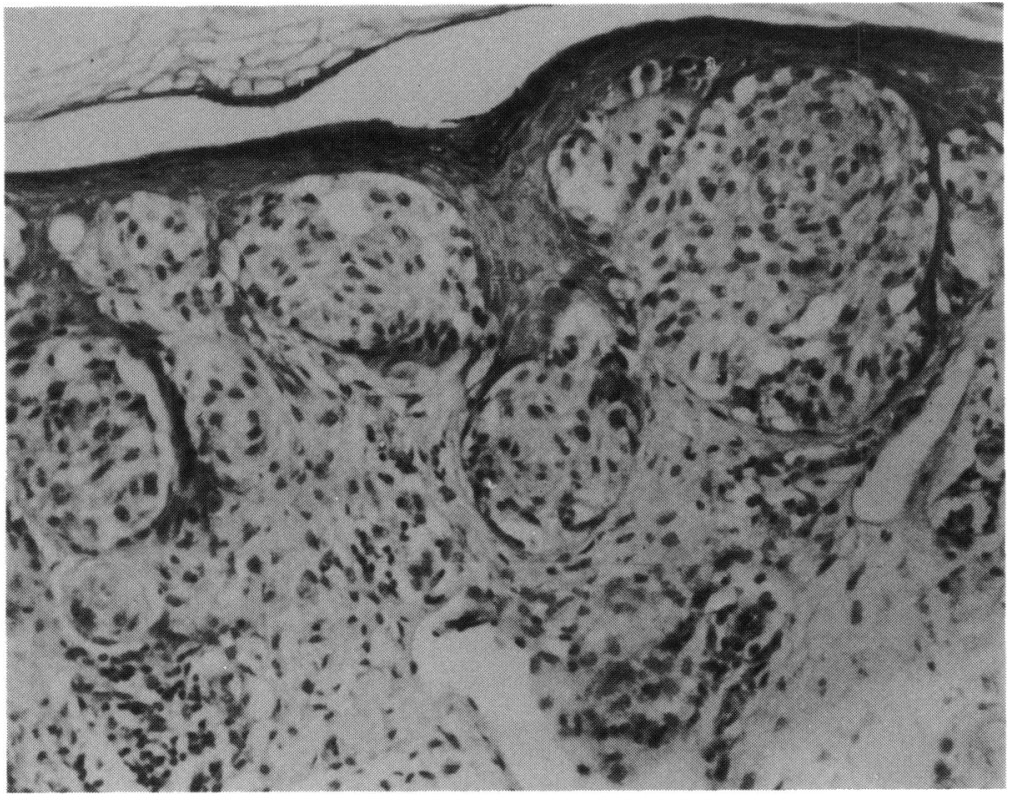

Fig. 4 Case 6. Superficial spreading malignant melanoma. The epidermis is infiltrated by clusters of lightly pigmented melanocytes with minor invasion of the dermis. (Haematoxylin and eosin, $\times 160)$. 
Fig. 5 Case 3. Superficial spreading malignant melanoma. The epidermis is infiltrated and partially destroyed by groups of tumour cells that have abundant cytoplasm containing fine melanin granules. (Haematoxylin and eosin, $\times 400)$.

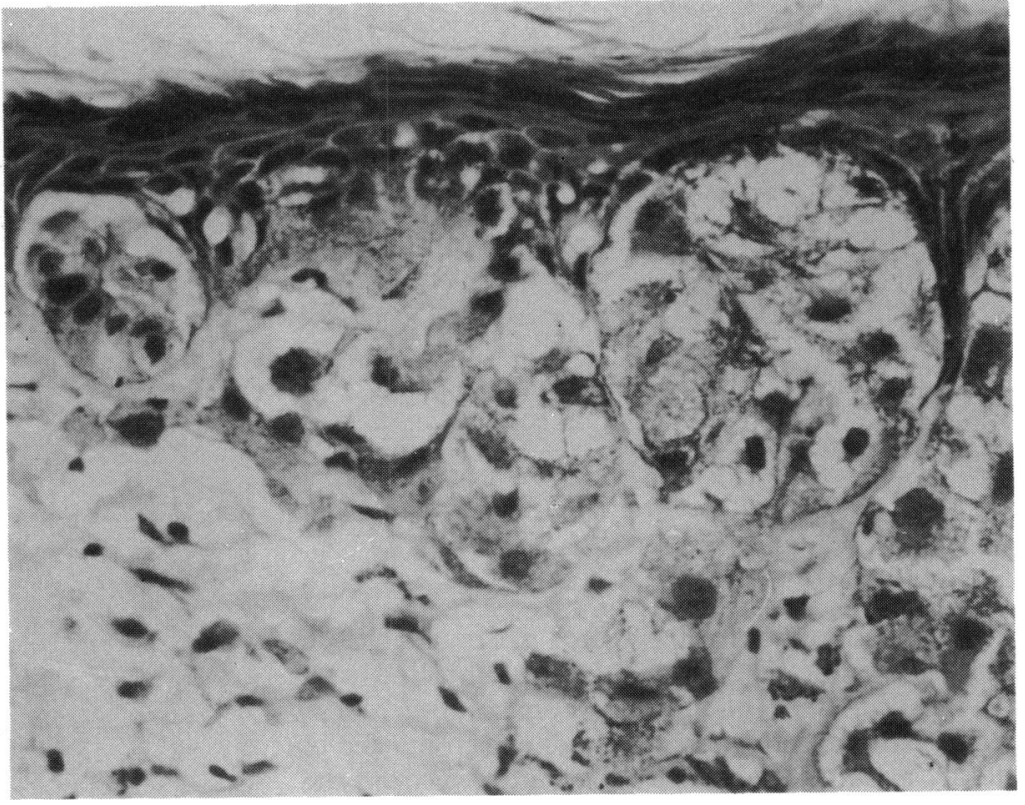

invasion not confined to the basal layer by cells with appreciable cytoplasm containing, in all but one instance, a light dusting with melanin (Figs. 3-5). There was variable stromal invasion, and the maximum thickness of the tumour ranged from 0.1 to
Fig. 6 Case 10. Nodular malignant melanoma. There is minimal lateral spread of a fairly discrete tumour that involves both the conjunctiva and skin at the lid margin. (Haematoxylin and eosin, $\times 15$ ).

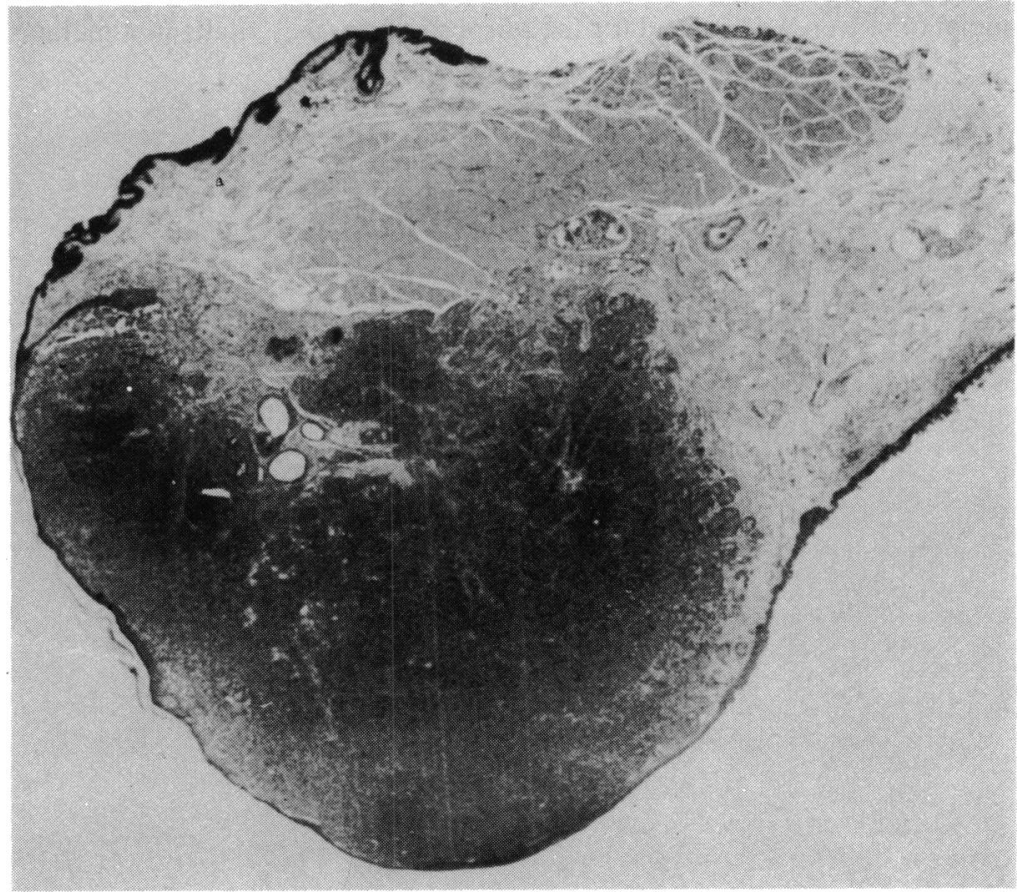




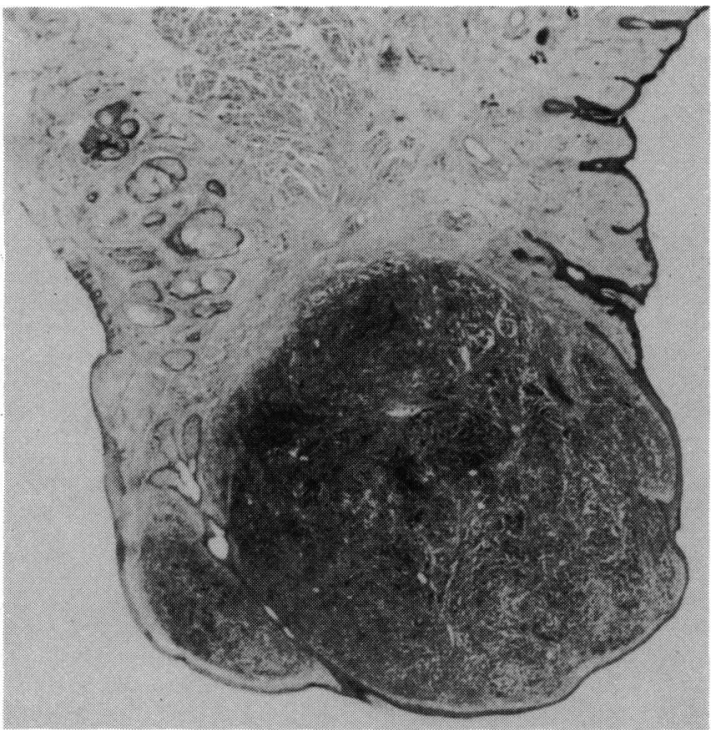

Fig. 7 Case 12. Nodular malignant melanoma. A welldefined pigmented tumour located at the eyelid margin. (Haematoxylin and eosin, $\times 14$ ).

$2.2 \mathrm{~mm}$, mean $0.55 \mathrm{~mm}$. In two cases (Nos. 2 and 7) the lesion was essentially in situ with minimal evidence of stromal invasion. Mitotic figures were generally inconspicuous.

In 12 cases the tumour was considered to be a nodular malignant melanoma in that there was extensive invasion of the subepithelial stroma with minimal evidence of junctional activity or lateral intraepidermal spread. The tumour appeared to have arisen in the region of the lid margin in four instances (Nos. 10, 12, 15, and 20) where the epidermis and conjunctival epithelium meet (Figs. 6 and 7). The maximum thickness of the tumours varied considerably, from 1.2 to $3.9 \mathrm{~mm}$ (mean $2.38 \mathrm{~mm}$ ). Cellular pleomorphism with variation in nuclear size, shape, and staining intensity was seen to a greater or lesser extent in all tumours, and in most the nucleoli were moderately or markedly conspicuous (Figs. 8-10). Mitotic figures were observed in all but three cases and in five exceeded an average of two per highpower field. The melanin content was variable, and five of the 12 cases appeared to be amelanotic.

The available sections in three cases were inadequate to allow recognition of the histological type, though the cytological features and evidence of stromal infiltration were such as to justify the diagnosis of malignancy.

No example of lentigo maligna melanoma was recognised.

\section{BEHAVIOUR}

Superficial spreading malignant melanoma. Posttreatment follow-up covered an average of $7 \cdot 4 \mathrm{yr}$, five of the nine patients being followed up for a minimum of five years. There were two tumour-related deaths, after seven and $12 \mathrm{yr}$, respectively, both having distant metastases.

Nodular malignant melanoma. The average length of follow-up after treatment of the initial lesion was

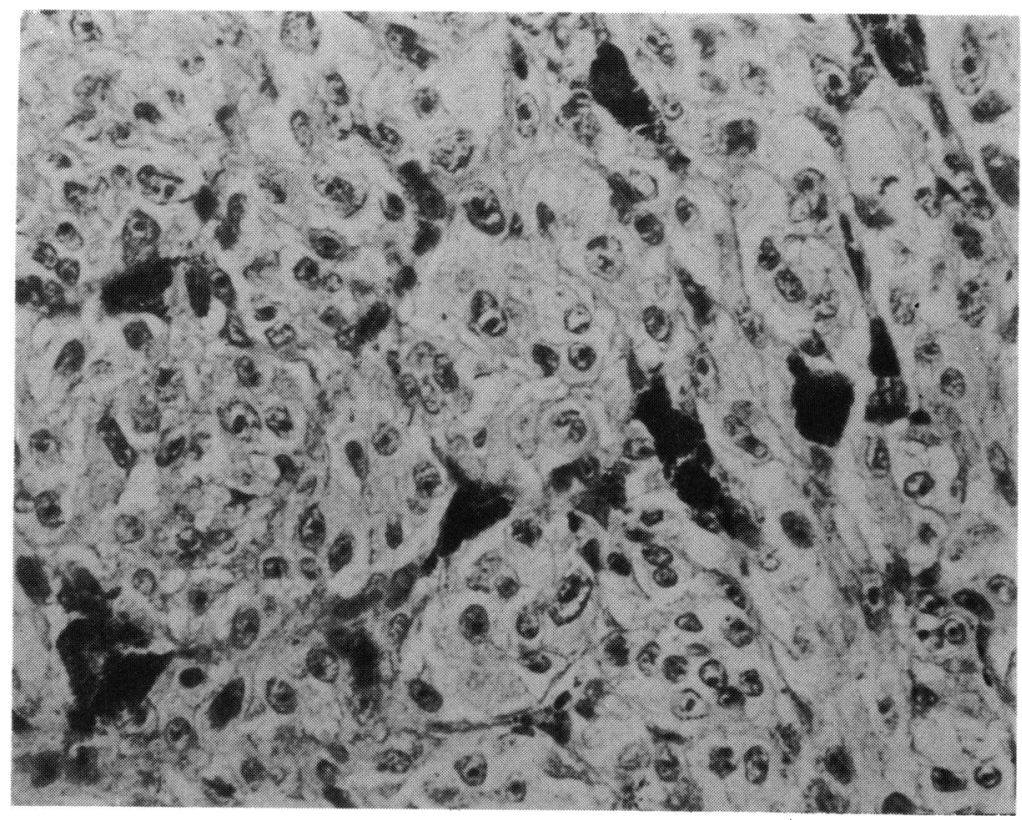

Fig. 8 Case 11. Nodular malignant melanoma. The tumour cells have generally abundant cytoplasm, contain varying amounts of pigment and conspicuous nucleoli. (Haematoxylin and eosin, $\times 400$ ). 
Fig. 9 Case 13. Nodular malignant melanoma. There is necrosis of the overlying epidermis, and the pleomorphic tumour cells have large, hyperchromatic nuclei. (Haematoxylin and eosin, $\times 400$ ).

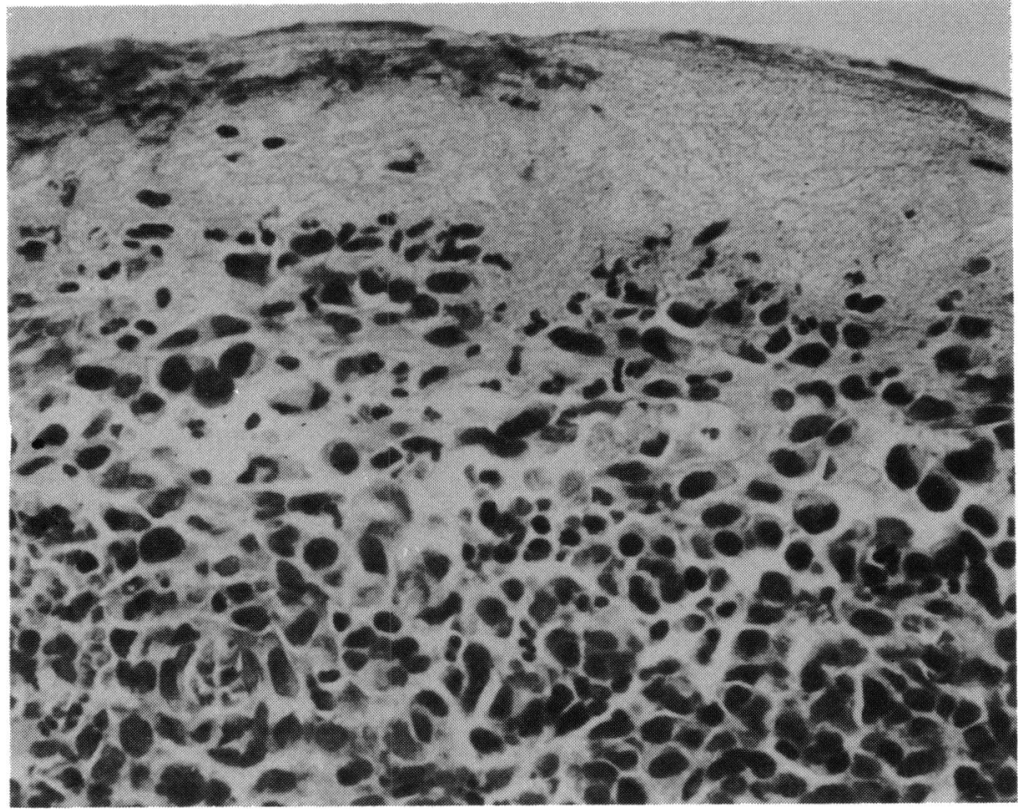

occurring some $10 \mathrm{yr}$ later. In one surviving patient (No. 21) the initial removal was incomplete, and a second surgical excision was required six months afterwards: she is alive and well four years after the first operation.

Unclassified malignant melanoma. The three patients in this group were followed up for 12, seven, and eight years respectively. The single fatality
Fig. 10 Case 19. Nodular malignant melanoma. Many of the cells are spindle-shaped and mitotic activity is evident. (Haematoxylin and eosin, $\times 400$ ).

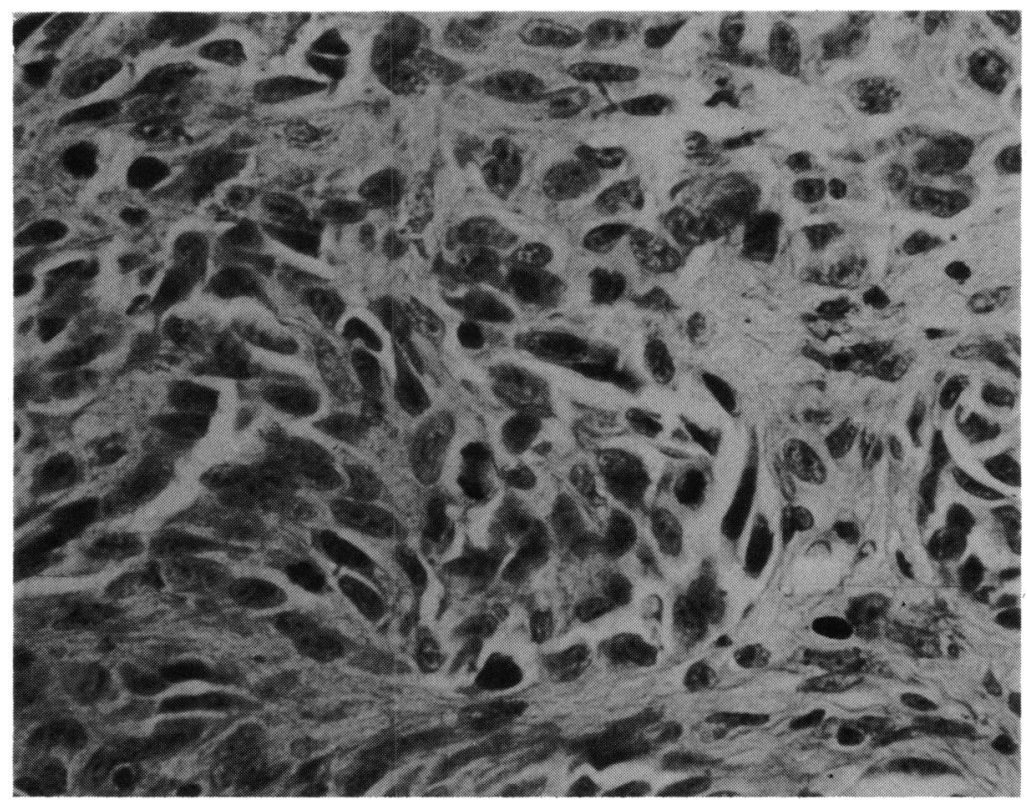


Table 1 Histopathological details and response to treatment in malignant melanoma of the eyelid skin

\begin{tabular}{|c|c|c|c|c|c|c|c|c|c|c|c|c|}
\hline \multirow{2}{*}{$\begin{array}{l}\text { Case } \\
\text { no. }\end{array}$} & \multirow[t]{2}{*}{ Age } & \multirow[t]{2}{*}{ Sex } & \multirow[t]{2}{*}{ Type } & \multicolumn{5}{|c|}{ Histology } & \multirow{2}{*}{$\begin{array}{l}\text { Initial } \\
\text { therapy }\end{array}$} & \multirow{2}{*}{$\begin{array}{l}\text { Recur. } \\
\text { (yr) }\end{array}$} & \multirow{2}{*}{$\begin{array}{l}\text { Follow-up } \\
(y r)\end{array}$} & \multirow[t]{2}{*}{ Comments } \\
\hline & & & & $\begin{array}{l}\text { Thick- } \\
\text { ness } \\
(\mathrm{mm})\end{array}$ & Melanin & Mitoses & $\begin{array}{l}\text { Pleo- } \\
\text { morphism } \\
\text { atypia }\end{array}$ & Nucleolus & & & & \\
\hline 1 & 52 & $\mathbf{F}$ & Superficial & 0.4 & + & - & + & + & Excision & - & Alive 3 & \\
\hline 2 & 58 & $\mathbf{F}$ & Spreading & $0 \cdot 1$ & + & - & + & \pm & $"$ & - & Alive 4 & In situ \\
\hline 4 & 61 & $\mathbf{M}$ & $"$ & - & \pm & - & + & \pm & $"$ & & Dead 12 & $\begin{array}{l}\text { Thickness } \\
\text { not measurable }\end{array}$ \\
\hline 5 & 69 & $\mathbf{F}$ & $"$ & $2 \cdot 2$ & - & \pm & \pm & \pm & Excision & - & Alive 10 & \\
\hline 6 & 62 & $\mathbf{M}$ & $"$ & $0 \cdot 5$ & + & - & \pm & \pm & $"$ & - & Alive 3 & \\
\hline 7 & 37 & $\mathbf{F}$ & $"$ & $0 \cdot 2$ & + & \pm & + & + & $"$ & $-\cdot$ & Alive 10 & $\begin{array}{l}\text { In situ with early } \\
\text { invasion }\end{array}$ \\
\hline 8 & 65 & $\mathbf{F}$ & $"$ & 0.3 & + & \pm & + & + & $"$ & - & Alive 4 & \\
\hline 10 & 55 & $\mathbf{M}$ & Nodular & $3 \cdot 3$ & - & + & + & \pm & $"$ & - & Dead 2 & $\begin{array}{c}\text { Metastases after } \\
\text { after } 11 / 2 \text { yrs }\end{array}$ \\
\hline 11 & 65 & $\mathbf{F}$ & $"$ & $3 \cdot 2$ & \pm & + & + & + & $"$ & $1 / 2$ & Alive 7 & $\begin{array}{l}\text { Initial removal } \\
\text { incomplete }\end{array}$ \\
\hline 12 & 39 & $\mathbf{M}$ & $"$ & $2 \cdot 9$ & - & + & + & \pm & $"$ & - & Alive 17 & \\
\hline 13 & 50 & $\mathbf{F}$ & $"$ & $>2 \cdot 5$ & \pm & + & + & \pm & $"$ & - & Alive 7 & \\
\hline 14 & 24 & $\mathbf{F}$ & $"$ & 1.4 & - & - & + & \pm & $"$ & - & Alive 14 & \\
\hline 15 & 35 & $\mathbf{M}$ & $"$ & $1 \cdot 7$ & \pm & - & \pm & $\overline{ \pm}$ & $"$ & - & Dead 5 & $\begin{array}{l}\text { Lymphnode and } \\
\text { cerebral } \\
\text { metastases }\end{array}$ \\
\hline 16 & 57 & $\mathbf{M}$ & $"$ & $2 \cdot 5$ & - & \pm & \pm & + & $"$ & - & Dead 11 & $\begin{array}{l}\text { Block dissection } \\
1971 \text { (cervical } \\
\text { node } \\
\text { metastasis, } \\
\text { died 1981) }\end{array}$ \\
\hline 17 & 43 & $\mathbf{F}$ & $"$ & $1 \cdot 2$ & + & - & + & \pm & $"$ & - & Alive 33 & $\begin{array}{r}\text { Evidence of pre- } \\
\text { ceding naevus }\end{array}$ \\
\hline 19 & 18 & $\mathbf{F}$ & $"$ & 3.9 & \pm & \pm & + & \pm & $"$ & - & Alive 6 & \\
\hline 20 & 64 & $\mathbf{M}$ & $"$ & $1 \cdot 4$ & \pm & + & + & - & $"$ & 1 & Dead 1 & $\begin{array}{l}\text { Died post-op. } \\
\text { (recurrence) }\end{array}$ \\
\hline 21 & 68 & $\mathbf{M}$ & $"$ & $3 \cdot 0$ & + & \pm & + & + & $"$ & $1 / 2$ & Alive 4 & $\begin{array}{c}\text { Initial removal } \\
\text { incomplete }\end{array}$ \\
\hline 22 & 80 & $\mathbf{F}$ & $\begin{array}{l}\text { Unclassi } \\
\text { fiable }\end{array}$ & - & - & + & + & + & $\begin{array}{l}\text { Excision/ } \\
\text { irradiation }\end{array}$ & & Dead 12 & $\begin{array}{l}\text { Died natural } \\
\text { causes }\end{array}$ \\
\hline 23 & 69 & $\mathbf{F}$ & " & $<5.5$ & + & + & + & + & Excision & - & Alive 7 & \\
\hline 24 & 74 & $\mathbf{F}$ & $"$ & - & - & \pm & \pm & \pm & $"$ & - & Alive 8 & \\
\hline
\end{tabular}

concerned the first of them (No. 22), an 80-year-old female who died of natural causes at the age of 92 years. Findings in individual cases are given in Table 1.

\section{Discussion}

Dermatopathologists commonly distinguish three types of cutaneous malignant melanoma. In our series we identified the nodular and superficial spreading forms but not the melanoma arising from a Hutchinson's freckle (lentigo maligna). This is unlikely to be a significant omission, however, others having described both the preinvasive ${ }^{6}$ and invasive form $^{7}$ of the latter variant in the eyelids.

Superficial spreading malignant melanoma was diagnosed in nine patients $(37.5 \%$ of the total), which is below the $70 \%$ incidence cited for the skin in other sites. ${ }^{8}$ In two of these cases the proliferation was largely intraepithelial, with minor evidence of deep invasion. Although the intraepidermal component was pigmented in all but one case, the melanin content of the stromal component was usually less evident, while the cells in this region were often spindle-shaped. The overall survival in this group, i.e., two tumour-related deaths in nine patients followed up for three to 14 years, is comparable to the $31 \%$ mortality after 5 years pertaining to this type of melanoma in general.

Nodular malignant melanoma was the most frequent variant in our series $(50 \%$ of the total), which is considerably in excess of the $12 \%$ cited for 
skin melanoma as a whole. ${ }^{911}$ In four patients the tumour appeared to have originated at the lid margin and proliferated to create a fairly discrete compact nodule, with variable cytological pleomorphism and a dearth of pigment: two of these cases died as a result of metastasis and one who is alive and well needed further treatment for a local recurrence. The fourth also suffered a local recurrence and died a few hours after surgery on this account. The prognosis for tumours of the nodular variety in other situations is generally worse than for other types of cutaneous melanoma, an overall five-year survival of $44 \%$ having been quoted." Consequently the $25 \%$ mortality (16.7\% after five years) for the 12 patients with this type of melanoma in the eyelid, seven of whom have survived more than five years, compares favourably with nodular malignant melanoma presenting at other sites. Early diagnosis and treatment prompted by the conspicuous location of the tumour may be a factor in the relatively better prognosis. But it is possibly patients with a nodular lesion developing at the mucocutaneous lid margin who are at greatest risk, since two of four such cases have had a fatal outcome and a third developed a local recurrence, whereas only one of eight patients in whom the tumour was confined to the skin has died. The cause of this unexpected finding is obscure, but specific aspects of eyelid anatomy 'may be involved, particularly the presence of efferent blood and lymph vessels at the margin, together with repeated minor trauma occasioned by blinking.

The prognosis of cutaneous malignant melanoma relates also to the depths of invasion. ${ }^{11} 12 \mathrm{~A}$ similar consideration applies to malignant melanoma of the conjunctiva, where a thickness of under $1.5 \mathrm{~mm}$ usually implies a favourable outcome after treat ${ }^{3}$ ment. ${ }^{1314}$ The maximum tumour thicknesses in the four patients with a fatal outcome in whom it was possible to take measurements were $0 \cdot 5,3 \cdot 3,1 \cdot 7,2 \cdot 5$ $\mathrm{mm}$ respectively. There were, however, eight patients in whom the tumour measured $1.5 \mathrm{~mm}$ or more who were alive and well at the time of review. To some extent the curvature of the eyelid at the margin where it meets the conjunctiva makes it difficult to determine the point from which measurements of thickness should be made, but even with this allowance the impression gained is that, size for size, malignant melanoma of the eyelid skin has a slightly better prognosis than its counterpart elsewhere. Whether a grading based on the tissue level reached by the invading tumour is applicable to the eyelid is debatable, since the total dermis (both papillary and reticular) is exceptionally thin in this region, and a stage V melanoma on the Clark et al. ${ }^{\text {" }}$ scale would often be a much smaller lesion than such staging would represent in other parts of the integument. For this reason we have chosen to confine ourselves to simple thickness measurements.

The generally good response to surgical excision suggests that this is the preferred treatment. Of the 21 patients with surgery three had a tumour related death, but both the patients treated with irradiation died with metastases. In none of the patients treated with primary surgery was there evidence of local recurrence. Only two patients developed cervical lymphnode metastases, one of them undergoing a cervical block dissection, but the other had cerebral metastasis diagnosed at the same time.

Finally we consider that the possible late presentation of metastases means that this and any similar study must follow up patients for at least 15 years.

The authors thank Miss G Chrysanthopoulou, Miss R Hart, Mrs P Goodwin, Dr J M Henk, P v Heerde, and Miss J A M Haages for their co-operation and aid in this study. We also thank the several unnamed surgeons for their unequivocal and prompt return of the questionnaires.

\section{References}

1 Henkind P, Friedman A. Cancer of the lids and ocular adnexa. In: Andrade R, Gumport SL, Popkin GL. Cancer of the skin: biology, diagnosis, management. Philadelphia: Saunders, 1976; 13: 45-71.

2 Batsakis J. Tumors of the head and neck. Baltimore: Williams and Wilkins, 1974.

3 Levene A. On the histological diagnosis and prognosis of malignant melanoma. J Clin Pathol 1980; 33: 101-24.

4 McGovern VJ, Mihm MC, Bailly C, et al. The classification of malignant melanoma and its histologic reporting. Cancer 1973; 32: $1446-57$.

5 Kopf AW, Bart RS, Rodriguez-Sains RS. Malignant melanoma: a review. J Dermatol Surg Oncol 1977; 3: 41-125.

6 Rodrigucz-Sains RS, Jakobiec FA, Iwamoto T. Lentigo maligna of the lateral canthal skin. Ophthalmology 1981; 88: 1186-92.

7 Naidoff MA, Bernardino VB, Clark WH. Melanocytic lesions of the cyclid skin. Am J Ophthalmol 1981; 82: 371-82.

8 Clark WA Jr, Ainsworth AM, Bernardino EA, et al. The developmental biology of primary human malignant melanomas. Semin Oncol 1975; 2: 83-103.

9 Kopf AW, Bart RS, Rodriguez-Sains RS, Ackerman AB. Malignant melanoma. New York: Masson, 1979.

10 Clark WII, From L, Bernardino EA, Mihm MC. The histogenesis and biologic behaviour of primary human malignant melanomas of the skin. Cancer Res 1969; 29: 705-26.

11 Breslow A. Tumor thickness, level of invasion and node dissection in stage 1 cutaneous melanoma. Ann Surg 1975; 182: 572-5.

12 McGovern VJ. The classification of melanoma and its relationship with prognosis. Pathology 1970; 2: 85-98.

13 Silvers DN, Jakobiec FA, Frecman TR, Lefkowitch JH, Elie RC. Melanoma of the conjunctiva: a clinicopathologic study. In: Jakobicc FA, ed. Ocular and adnexal tumors. Birmingham, Ala: Acsculapius, 1978: 583-99.

14 Liesegang TJ, Campbell RJ. Mayo Clinic experience with conjunctival melanomas. Arch Ophthalmol 1980; 98: 1385-9. 